\title{
Nilai-Nilai Sportifitas Dalam Seni Pertunjukan Peresean Masyarakat Sasak Lombok
}

\author{
Ali Imran ${ }^{1}$ \& Wahyu Hananingsih ${ }^{2}$ \\ ${ }^{1}$ Dosen Universitas Pendidikan Mandalika Mataram \\ ${ }^{2}$ Dosen Universitas Islam Negeri Mataram \\ Email: alilombok84@gmail.com, wahyuhananingsih@uinmataram.ac.id
}

\begin{abstract}
Abstrak. Peresean adalah pertarungan antara dua lelaki yang bersenjatakan tongkat rotan (penjali) dan berperisai kulit kerbau yang tebal dan keras (perisai disebut ende). Tradisi ini dilakukan oleh masyarakat suku Sasak, Lombok, Nusa Tenggara Barat, Indonesia. Petarung dalam Peresean biasanya disebut pepadu dan wasit disebut pakembar. Budaya peresean yang di mainkan oleh masyarakat Lombok suku Sasak terlihat seram dan menakutkan, namun jika ditelusuri lebih mendalam banyak nilai-nilai yang tersimpan dan terkandung didalamnya, antara lain nilai seni, kesatria, persaudaraan, dan nilai sportifitas. Tujuan penelitian ini adalah mengetahui nilai-nilai sportifitas dalam seni pertunjukan peresean. Penelitian ini merupakan penelitian deskriptif. Metode yang digunakan adalah survey dan pengumpulan data penelitian ini melalui observasi dan wawancara. Lokasi penelitian berada di desa darek kecamatan praya barat daya kabupaten lombok tengah. Subyek dalam penelitian ini adalah payuguban panji kartike di Desa Darek. Hasil penelitian ini menunjukan bahwa nilai-nilai sportifitas dalam seni pertunjukan peresean masyarakat sasak lombok meliputi sikap yang selalu mengedepankan kejujuran (sikap dan perilaku para pepadu yang secara jantan mau mengakui keunggulan lawan dan menerimanya dengan lapang dada) sikap yang selalu menghormati lawan tanding atau pepadu lain, selalu taat terhadap aturan pertandingan (rules of game).
\end{abstract}

\section{Kata kunci : Nilai-Nilai, Sportifitas, Peresean, Masyarakat Lombok}

\section{PENDAHULUAN}

Pulau Lombok adalah pulau yang terkenal dengan daerah tujuan wisata dan budaya nya tidak jarang wisatawan di Lombok juga teratarik dengan atraksi lokal di pulau Lombok salah satunya adalah presean Kesenian dari Pulau Lombok satu ini merupakan media untuk para lelaki dalam menguji keberanian dan ketangguhan mereka. Peresean adalah kesenian atau atraksi lokal masyarakat Suku Sasak yang mempertarungkan dua lelaki yang bersenjatakan tongkat rotan dan perisai yang terbuat dari papan kayu yang sudah di siapkan panitia Kesenian ini merupakan tradisi yang lama yang berasal dari Suku Sasak di Pulau Lombok provinsi NTB, yang keberadaanya masih ada hingga sekarang. Dalam kesenian tersebut para lelaki berkumpul untuk menguji keberanian dan ketangkasan mereka dalam bertarung. Walaupun terdapat unsur kekerasan, namun kesenian ini memiliki pesan damai didalamnya.
Menurut sumber sejarah yang ada, peresean ini dulunya merupakan luapan emosional para raja dan para prajurit setelah memenangkan pertempuran di medan perang. Selain itu peresean ini juga merupakan media untuk para petarung dalam menguji keberanian, ketangguhan dan ketangkasan mereka dalam bertarung. Kesenian ini terus berlanjut sampai sekarang di kalangan masyarakat Suku Sasak hingga menjadi suatu tradisi. Dalam perkembangannya, kesenian ini tidak hanya diadakan untuk masyarakat lokal saja, namun juga digelar untuk menyambut para tamu besar atau wisatawan yang berkunjung ke sana.

Seperti yang disebutkan di atas, kesenian ini merupakan media bagi para petarung atau para lelaki dalam menguji keberanian, ketangguhan, dan ketangkasan mereka. Walaupun terdapat unsur kekerasan di dalamnya, namun peresean memiliki pesan damai. Setiap petarung yang ikut dalam pertunjukan tersebut dituntut memiliki jiwa 
pemberani, rendah hati, dan tidak pendendam. Dalam pertunjukannya, Peresean biasanya digelar di tempat yang cukup luas, agar ruang gerak para petarung tidak sempit dan para penonton juga bisa menyaksikan. Dalam pertarungan tersebut terdapat dua orang petarung yang disebut dengan Pepadu dan tiga orang wasit yang mengatur jalannya pertandingan. Salah satu wasit yang mengawasi jalannya pertandingan disebut dengan Pakembar Tengah, dan wasit yang memilih para pepadu disebut pakembar sedi. Pertarungan tersebut biasanya dilakukan dalam lima ronde dengan durasi tiga menit setiap rondenya. Sebelum pertandingan dimulai Pepadu akan di berikan instruksi dan doa agar pertandingan berjalan lancar. Setelah itu wasit akan memukul ende dengan rotan sebagai tanda pertarungan dimulai.

Dalam pertarungan peresean ini terdapat beberapa peraturan, diantaranya pepadu tidak boleh memukul badan bagian bawah seperti paha atau kaki, tapi pepadu diperbolehkan memukul bagian atas seperti kepala, pundak atau punggung. Setiap pukulan tersebut memiliki nilai masing-masing, dan pemenang dalam Peresean ini biasanya ditentukan dari nilai yang diperoleh setiap rondenya. Selain itu para Pepadu tersebut dinyatakan kalah apabila sudah menyerah atau berdarah.

Apabila ada Pepadu mengalami luka atau berdarah, tim medis akan mengobatinya dengan obat sejenis minyak khusus agar tidak menimbulkan rasa perih. Setelah bertarung para pepadu kemudian bersalaman dan berpelukan, sebagai tanda damai dan tidak ada dendam diantara mereka, hal inilah yang mendasari peneliti untuk mengetahui nilainilai sportifitas yang terkandung di dalam pertunjukan peresean yang ada di masyarakat sasak Lombok.

\section{METODE PENELITIAN}

Penelitian ini merupakan penelitian deskriptif. Lokasi penelitian berada di desa darek, kecamatan praya barat daya, kabupaten Lombok Tengah , Provinsi Nusa Tenggara Barat. Subyek dari penelitian ini adalah paguyuban panji kartike di desa darek, dalam penelitian ini, data dikumpulkan melalui observasi dan wawancara untuk menghimpun informasi seputar bilai-nilai sportifitas dalam seni pertunjukan peresan pada masyarakat. Adapun proses analisis dilakukan dalam beberapa tahapan yang meliputi pengumpulan data, reduksi data, penyajian data dan kesimpulan/ verifikasi data dalam bentuk laporan penelitian.

\section{HASIL DAN PEMBAHASAN}

\section{Nilai-Nilai Sportifitas dalam Seni Pertunjukan Peresean di Desa Darek Kecamatan Praya Barat Daya Kabupaten Lombok Tengah.}

"Hasil wawancara dengan pengurus paguyuban panji kartike peresean Lombok yaitu Bapak Ahmad Fauzan "Peresean atau tradisi bertarung dengan rotan adalah budaya dari suku sasak yang hingga kini masih dilakukan. Warisan kekayaan budaya di Gumi Lombok Sileparang ini tergolong unik dan menjadi daya tarik tersendiri bagi para wisatawan lokal maupun mancanegara. Selain unik, tradisi ini terbukti memang memacu adrenalin bagi yang menontonnya. Bagaimana tidak? Penonton yang menyaksikan peresean adat Lombok ini harus memiliki cukup keberanian untuk menyaksikan pertarungan ini.

Pertarungan sengit para pemain yang profesional, dengan menggunakan senjata rotan yang bisa melukai tubuh petarung hingga mengeluarkan darah. Namun, pertarungan dalam tradisi peresean Lombok ini bukan sembarang pertarungan. Terdapat nilai sportifitas dan sekaligus nilai patriotisme yang begitu mendalam yang berkaitan dengan sejarah Suku Sasak Lombok.

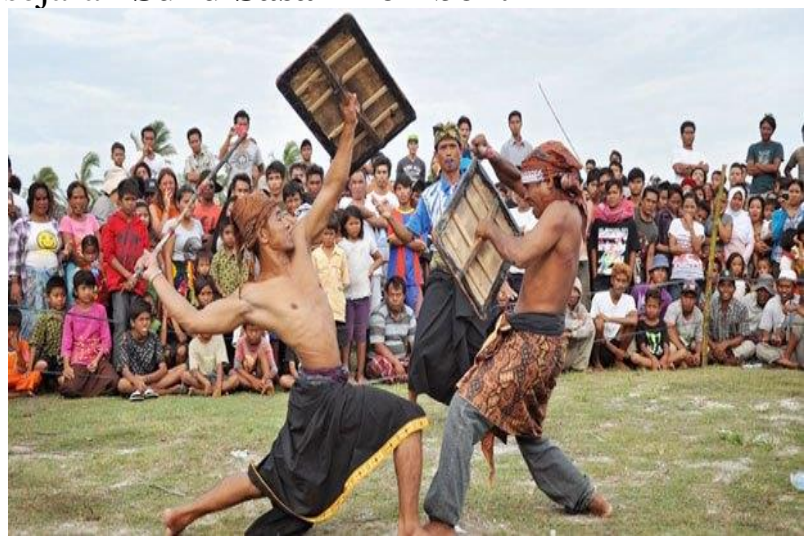

Gambar : Pertunjukan Peresean 
Setelah lewat masa penjajahan, pertarungan ini terus dilakukan secara turuntemurun hingga menjadi tradisi Suku Sasak. Tradisi ini kemudian diyakini juga oleh masyarakat sebagai ritual meminta hujan saat musim kemarau panjang tiba. Seiring perkembangan zaman dan kepopuleran Lombok sebagai daerah wisata, tradisi peresean bukan hanya untuk ritual dan acara kerajaan, melainkan juga menjadi daya tarik luar biasa untuk menyambut para wisatawan yang berkunjung, karena bukan merupakan pertarungan biasa dan mengandung makna filosofis yang kuat, para petarung dalam tradisi seni peresean ini diwajibkan menggunakan baju adat khas Lombok.

Para petarung yang biasa disebut pepadu menggunakan celana yang dibalut dengan penutup kain khas Lombok dan kain ikat kepala. Pada bagian atasnya, mereka tidak menggunakan baju apapun alias bertelanjang dada. Sementara itu, alat tarung yang digunakan hanyalah sebuah perisai yang merupakan bagian dari senjata dan tongkat rotan untuk bertarung.

Selama

pertarungan

berlangsung, pepadu akan diawasi oleh wasit atau disebut pekembar.

Ada dua pekembaryang mengawasi jalannya pertarungan, yaitu pekembar sedi yang mengawasi jalannya pertarungan dari luar arena, dan pekembar tengah yang mengawasi jalannya Peresean di tengah arena.

Selama upacara ini berlangsung, masing-masing pepadu saling serang menggunakan tongkat rotan dan menangkis menggunakan perisai yang terbuat dari kulit kerbau yangtebal. Satu yang membuat tradisi Peresean ini menjadi begitu seru dan menantang adalah para рераdu sama sekali tidak memiliki persiapan dan tidak mengetahui siapa lawan tarungnya. Orang yang bertindak memilih para pepadu adalah pekembar sedi dan mereka yang terpilih harus bersedia melakukan pertarungan. Jadi, pertarungan yang dilakukan betul-betul dilakukan secara spontan oleh warga Suku Sasak Lombok ini.

Pertarungan dalam tradisi peresean baru akan berhenti ketika salah satu pepadu ada yang terluka hingga berdarah. Jika salah satu dari pepadu belum ada yang terluka, keduanya dianggap sama kuat dan pertandingan dilanjut hingga melewati lima ronde barulah ditentukan siapa yang paling sedikit mengalami luka.

Tidak mutlak lima, banyaknya ronde bisa disesuaikan dengan kesepakatan bersama antar panitia dan pekembar. Meski dikenal dengan tradisi pertarungan, setiap selesai bertarung masing-masing pepadu wajib berpelukan dan saling memaafkan seakan tak pernah terjadi apapun sebelumnya. Ini menunjukkan nilai-nilai sportifitas yang tinggi meliputi sikap dan perilaku para pepadu yang secara jantan mau mengakui keunggulan lawan dan menerimanya dengan lapang dada dan kesabaran, kerendahan hati, dan saling menghormati yang sangat kental dicontohkan dalam tradisi ini.

\section{SIMPULAN}

Tradisi peresean adalah kesenian tradisional masyarakat Suku Sasak yang mempertarungkan dua laki -laki ( pepadu) dengan memakai senjata dari tongkat rotan dan perisai. Dalam tradisi peresean ada aturan atau awiq-awiq dan juga sanksi dalam pelaksanaannya. Tradisi peresean merupakan salah satu tradisi masyarakkat sasak Lombok yang dijadikan media untuk unjuk ketangguhan seorang laki - laki. Nilai -nilai sportifitas yang terdapat dalam tradisi peresean adalah mengenai nilai-nilai tentang sportifitas seperti sikap yang selalu mengedepankan kejujuran (sikap dan perilaku para pepadu yang secara jantan mau mengakui keunggulan lawan dan menerimanya dengan lapang dada) sikap yang selalu menghormati lawan tanding atau pepadu lain, selalu taat terhadap aturan pertandingan (rules of game).

Bagi Paguyuban Panji Kartike diharapkan untuk terus melestarikan tradisi seni pertujukan peresean mulai dari sejak usia dini, sehingga dari dini nilai sportifitas akan tertanam pada diri pribadi pepadu sejak dini. Dan bagi pemerintah diharapkan lebih ikut memotivasi dan membantu dalam pengembangan eksistensi budaya-budaya yang 
ada di Lombok, sehingga kelestarian budaya masayarakat Lombok dapat terjaga agar tidak punah.

\section{DAFTAR PUSTAKA}

I Made Ardika Yasa. 2020.Nilai-Nilai Pendidikan dalam Budaya Tarung Peresean di Lombok Barat. E-journal (http://ejournal.ihdn.ac.id/index.php/ JPAH. NilaiNilai_Pendidikan_Dalam_Budaya_T arung_Presean_Di_Lombok_Barat_P erspektif_Agama_Hindu/link/5ec2cc 0d92851c11a870c3ca.

Nilai dan pesan moral peresan Lombok.

http://bagas420.blogspot.com/2018/0

5/nilai-dan-pesan-moral-preseanlombok.html. diakses pada tanggal 20 februari 2021 pukul 11.00 Wita.

Peresean Adat Lombok Budaya Sasak yang Unik dan Tradisional. https://www.lomboktourplus.com/per esean-adat-lombok/ . diakses pada tanggal 21 februari 2021 pukul 11.00 Wita.

Suratman, dkk. 2013. Imu Sosial Dan Budaya Dasar. Malang: Intimedia.

Yusuf, M. Peresean Budaya Suku Sasak Yang Lestari .E-Journal (http:// www.ejournal-murahyusuf.info/ 2018/ 02/ peresean-budaya-suku-sasak-yanglestari.html) 